\title{
Analysis of the variability of sugar beet (Beta vulgaris $L$ ) growth during the early stages. II. Factors influencing seedling size in field conditions
}

\author{
C Durr 1, J Boiffin 1, A Fleury 2, I Coulomb 3 \\ 1 INRA, Station d'Agronomie de Laon-Péronne, BP 101, 02004 Laon Cedex; \\ 2 INAPG, Chaire d'Agronomie, Route de Thiverval, 78850 Grignon; \\ ${ }^{3}$ INRA, Laboratoire d'Agronomie, Route de Thiverval, 78850 Grignon, France
}

(Received 15 January 1992; accepted 4 May 1992)

\begin{abstract}
Summary - The variability of sugar beet seedling size, evaluated at the 4-leaf stage, was studied in field experiments in which seedbed structure and seed placement varied widely. Seedling size was dependent on processes occurring before emergence. Emergence delay was associated with poor seedling size. Even when emergence delays were the same, seedling size depended on environmental conditions: mechanical obstacles (crusts, clods) were associated with small seedlings. Seedbed preparation and seed placement can have a significant influence on the early growth of sugar beet through seedling size distribution, as well as through emergence rate and duration.
\end{abstract}

Beta vulgaris $\mathrm{L}=$ sugar beet / seedling size / seedbed conditions / emergence delay / sowing depth / soil crusting

Résumé - Variabilité des courbes de croissance de la betterave sucrière (Beta vulgaris L) au stade jeune. II. Facteurs influençant la taille des plantules. La variabilité des états de croissance précoce des plantules de betterave sucrière a été étudiée dans des expérimentations au champ faisant varier l'état structural du lit de semences et les profondeurs de semis. Les plantules sont caractérisées par la longueur de leur première feuille, $225^{\circ} \mathrm{C}$.j après la levée. Cet indice varie selon les conditions rencontrées par les plantules avant leur émergence. Plus le délai à l'émergence est long, plus la fréquence de plantules de faible taille est élevée. Par ailleurs, la taille des plantules ayant émergé le même jour dépend des conditions de milieu rencontrées avant émergence. Les plantules ayant été en contact avec un obstacle mécanique (mottes, croûtes superficielles) sont en moyenne plus petites. Ces résultats indiquent que les modalités de préparation des lits de semences et de semis se répercutent sur le début de croissance, non seulement en jouant sur les taux et vitesses de levée, mais également en modifiant la croissance des plantules entre l'émergence et l'apparition de la deuxième paire de feuilles vraies.

Beta vulgaris $L=$ betterave sucrière / taille des plantules / lit de semences / durée de levée / profondeur de semis / croûte de battance

\section{INTRODUCTION}

Sugar beet establishment appears to be a critical crop stage in the northern part of its cropping area. Difficult conditions can induce a lack of plants, delayed emergence, and slow growth after emergence. This leads to a slow increase of leaf cover, and hence to limited radiation interception (Scott and Jaggard, 1978; Milford et al, 1980). Since a successful crop implies fast and homogeneous early growth, it is useful to identify the main factors inducing growth variability before competition between plants begins, espe- cially those factors which can be controlled by agricultural practices.

We have previously shown (Boiffin et al, 1992) that differences in individual biomass measured in late June are greatly influenced by much earlier differences, which can be observed by the time the second pair of leaves appear. Various conditions at sowing appear to influence early growth via the initial seedling size and not via its subsequent relative growth rate.

The present study investigates some of the factors that determine this seedling size variability in field conditions, by analyzing the distribu- 
tions of seedling sizes in the experiments where the above results were obtained. Variations in seedling size are often attributed to differences in seed characteristics. In the case of sugar beet, the processes of plant breeding, seed production and seed processing lead to a particularly great variability of seed characteristics. Scott et al (1974) found that seed size strongly influenced plant growth. Such an influence has also been found for other cultivated species. The influence of environmental conditions on germination and emergence has been thoroughly investigated, particularly in the case of sugar beet. But their specific effect on the first stages of seedling growth has received less attention, apart from works on fertilizer placement (Scott and Blair, 1988; Durrant and Mash, 1989) and the effect of aggregate size (Hammerton, 1961; Donald et al, 1987).

The factors influencing seedling growth are difficult to identify, especially in field conditions, because of possible confusions with the effect of seedling age. Since seedling growth is exponen- tial, inaccurate seedling age can induce a large bias in seedling biomass comparisons. For this reason, particular attention has been paid to determining the age of plants. Thus, individual emergence times have been measured and soil temperatures monitored in order to estimate the actual physiological age of seedlings when seedling size was characterized.

\section{MATERIAL AND METHODS}

\section{Experimental conditions}

Experiments reported here were conducted in the same fields and years as described by Boiffin et al (1992). Experimental treatments (table I) were different soil types, seedbed structures, sowing depths, sowing dates, soil mulches, and artificial rainfall applications just after sowing.

Each 15-m long experimental plot was prepared by 2 passes of a 12-row drill (5.4-m wide). Rows bord-

Table I. Experimental design.

\begin{tabular}{|c|c|c|c|c|c|c|c|c|}
\hline Year & Site & $\begin{array}{l}\text { Top soil } \\
\text { texture (clay } \\
\text { content }(\%)\end{array}$ & $\begin{array}{l}\text { Sowing } \\
\text { date }\end{array}$ & Cultivar & $\begin{array}{l}\text { Seedbed } \\
\text { structure }\end{array}$ & $\begin{array}{l}\text { Sowing } \\
\text { depth } \\
(\mathrm{cm})\end{array}$ & $\begin{array}{l}\text { Plastic } \\
\text { mulch }\end{array}$ & Code \\
\hline 1987 & Laon & $\begin{array}{l}\text { Sandy loam } \\
(15.8)\end{array}$ & $\begin{array}{l}9 \text { April } \\
" ~\end{array}$ & $\begin{array}{c}\text { Bingo } \\
" \\
"\end{array}$ & $\begin{array}{l}\text { Fine } \\
\text { Fine } \\
\text { Fine }\end{array}$ & $\begin{array}{c}2.5 \\
11 \\
4.0\end{array}$ & $\begin{array}{l}\text { Yes } \\
\text { No } \\
"\end{array}$ & $\begin{array}{l}\mathrm{L} 1 \\
\mathrm{~L} 2 \\
\mathrm{~L} 3\end{array}$ \\
\hline & $\begin{array}{l}\text { Mons en } \\
\text { Chaussée }\end{array}$ & $\begin{array}{l}\text { Silt loam } \\
(19.0)\end{array}$ & $\begin{array}{l}7 \text { April } \\
" 1 \\
" \\
"\end{array}$ & " & $\begin{array}{l}\text { Fine } \\
\text { Coarse } \\
\text { Fine }\end{array}$ & $\begin{array}{c}2.5 \\
" \\
" \\
4.0\end{array}$ & $\begin{array}{l}\text { Yes } \\
\text { No } \\
" \\
"\end{array}$ & $\begin{array}{l}M 1 \\
M 2 \\
M 3 \\
M 4\end{array}$ \\
\hline & $\begin{array}{l}\text { St Pierre } \\
\text { Aigle }\end{array}$ & $\begin{array}{l}\text { Silt loam } \\
(11.7) \\
\text { Silt loam } \\
(18.3)\end{array}$ & 18 April & " & $\begin{array}{c}\text { Fine } \\
\text { " }\end{array}$ & $\begin{array}{c}2.5 \\
"\end{array}$ & $\begin{array}{l}\text { No } \\
\text { " }\end{array}$ & $\begin{array}{l}\mathrm{P} 1 \\
\mathrm{P} 2\end{array}$ \\
\hline & Aizecourt & $\begin{array}{l}\text { Calcareous } \\
\text { silty clay loam } \\
\text { (28.5) } \\
\text { Silt loam (22.5) }\end{array}$ & 16 April & $"$ & $\begin{array}{l}\text { Fine } \\
\text { " }\end{array}$ & 2.5 & No & $\mathrm{A} 2$ \\
\hline 1988 & $\begin{array}{l}\text { Mons en } \\
\text { Chaussée }\end{array}$ & $\begin{array}{l}\text { Silt loam } \\
(17.0)\end{array}$ & $\begin{array}{l}6 \text { April } \\
2 \text { May }\end{array}$ & Bingo & $\begin{array}{l}\text { Fine } \\
\text { Crusted (a) } \\
\text { Crusted (b) } \\
\text { Fine } \\
\text { Fine }\end{array}$ & $\begin{array}{c}2.5 \\
" 1 \\
" \\
" 1 \\
4.0\end{array}$ & $\begin{array}{l}\text { No } \\
" \\
" \\
" \\
"\end{array}$ & $\begin{array}{l}\text { C1 } \\
\text { C2 } \\
\text { C3 } \\
\text { C4 } \\
\text { C5 }\end{array}$ \\
\hline
\end{tabular}

(a) $7 \mathrm{~mm}$; (b) $14 \mathrm{~mm}$ rainfall (peak intensity $60 \mathrm{~mm} \mathrm{~h}^{-1}$ ) just after sowing. 
ering the tractor wheel passes were discarded, so that 16 rows with $50-100$ seedlings per row were available in each plot for observations.

Data collected from this experimental network were analyzed to detect non-random patterns of seedling size distribution in time and space, rather than for direct comparisons of experimental treatments. The time distribution of seedling size was studied in relation to emergence delay, which varied widely as a result of the experimental conditions. Space distribution was studied by comparing the size distribution of seedlings that emerged on the same day. These comparisons were made: i) between different plots on the same site and having the same sowing date, but different seedbed structures; ii) between different rows; and iii) between different areas having common features of surface structure, irrespective of the plot in which they were located.

Row effects were studied only in the 1988 experiments, because in this case 3 control plots were tilled and drilled one after the other on the same tractor passes; this allowed a sufficient number of same-day emergers to be observed in each row. The lateral heterogeneity of soil structure induced by wheel passes followed exactly the same pattern in all plots.

The consequences of structure degradation of the soil surface were studied in plots sown in 1988, and given 0,7 , or $14 \mathrm{~mm}$ artificial rainfall just after sowing. Until the end of emergence, almost no crusting occured on plots without artificial rainfall because natural rainfall occured at low intensities. The spatial distribution of the artificial rainfall was rather variable, so that differences in crust strength and thickness were as marked within plots as they were between plots. Two typical crust types were then distinguished and mapped, whatever the plot they were found in (Boiffin, 1984, 1986; Boiffin and Bresson, 1987; Bresson and Boiffin, 1990): i) structural crusts, corresponding to the beginning of crust development: ii) depositional crusts, corresponding to later stages with bedded microlayers in depressed areas.

Soil analyses indicated no nutrient deficiency or any other chemical disorder. Soil moisture, seed placement and climatic events after sowing were such that water availability was not limiting during the germination of all seeds.

The same seed lot (cv Bingo) was used on all plots for each experimental year.

\section{Observations and measurements}

The emergence date of each seedling was noted on a plastic label inserted in the soil. Seedling size was assessed by measuring its first leaf length when the thermal time from its emergence reached $225^{\circ} \mathrm{C}$ days (Fleury and Caneill, 1984). Thermal time (STT) was calculated on the basis of the soil temperature measured on each plot, $2.5 \mathrm{~cm}$ below the surface, and with a base temperature of $0^{\circ} \mathrm{C}$. Seedling size grade (SG) were defined from 1 to 5 as corresponding to leaf length intervals of 1-9 mm (SG 1); 10-19 (SG 2); 2029 (SG 3); 30-39 (SG 4); $40 \mathrm{~mm}$ and over (SG 5). The size grade was marked on the same label as the emergence date. This way of characterizing seedling growth had 2 practical advantages: it is nondestructive, allowing further observations on seedlings, and it allows the rapid characterization of many seedlings, which is important for avoiding confusion between plant age and plant growth rate. Emergence dates and SG were plotted on a map of each experimental plot.

A more detailed study of seedling characteristics and environment was realized on a subsample of 200 seedlings in 1988. This subsample was selected at random, but only in plots without artificial rainfall. For each sampled seedling, the seed depth was measured and the shape of root and hypocotyl was observed. Typical features of soil structure close to the seedling organs were also described, mainly clods or compact layers.

Additional observations were made on a restricted number of seedlings to i), describe their growth pattern before $225^{\circ} \mathrm{C}$ days, and ii), relate their size grade to earlier growth. For purpose i), the average increase in biomass was monitored by sampling 5 seedlings having the same emergence date at 8 times from 60 to $200{ }^{\circ} \mathrm{C}$ days. For purpose ii), a nondestructive method was required. Cotyledon elongation of 35 seedlings was monitored from emergence to $225^{\circ} \mathrm{C}$ days. The length of the first leaf was measured at this time, and a SG was attributed to each seedling.

\section{RESULTS}

\section{Influence of emergence delay on seedling size distribution}

Seedling size distributions were compared for days at the beginning and at the end of emergence, with at least $60{ }^{\circ} \mathrm{C}$ days between them. Those comparisons were made on plots where at least 25 seedlings had emerged on the latest days.

Table II shows that seedling size distributions were significantly different in 12 of the 16 cases. Plants with a low SG were more numerous for late emergence dates and there were smaller proportions of high SG (4 and 5) plants. Comparison of several emergence days for the same plot showed that the increase in the proportion of small plants was continuous (fig 1).

Then, for further analyses, the size grade distributions were compared by selecting plants having the same emergence date: since a given factor could modify emergence delay, direct ef- 
Table II. Seedling size of early and late emergers.

\begin{tabular}{|c|c|c|c|c|c|c|c|c|}
\hline \multirow[t]{2}{*}{ Treatment } & \multirow{2}{*}{$\begin{array}{l}\text { STT from } \\
\text { sowing to } \\
\text { emergence } \\
\left({ }^{\circ} \mathrm{C} \text { days) }\right.\end{array}$} & \multicolumn{5}{|c|}{ Size grade (\% seedlings) } & \multirow{2}{*}{$\begin{array}{c}\text { Sample } \\
\text { size } \\
\text { (n) }\end{array}$} & \multirow{2}{*}{$P\left(\chi^{2}\right)^{1}$} \\
\hline & & 1 & 2 & 3 & 4 & 5 & & \\
\hline L1 & $\begin{array}{l}115 \\
203\end{array}$ & $\begin{array}{r}2 \\
17\end{array}$ & $\begin{array}{r}4 \\
77\end{array}$ & $\begin{array}{r}48 \\
7\end{array}$ & $\begin{array}{r}44 \\
0\end{array}$ & $\begin{array}{l}1 \\
0\end{array}$ & $\begin{array}{r}207 \\
30\end{array}$ & $<1 \%$ \\
\hline L2 & $\begin{array}{l}116 \\
234\end{array}$ & $\begin{array}{r}1 \\
30\end{array}$ & $\begin{array}{r}8 \\
63\end{array}$ & $\begin{array}{r}72 \\
8\end{array}$ & $\begin{array}{r}19 \\
0\end{array}$ & $\begin{array}{l}0 \\
0\end{array}$ & $\begin{array}{r}126 \\
40\end{array}$ & $<1 \%$ \\
\hline L3 & $\begin{array}{l}120 \\
213\end{array}$ & $\begin{array}{r}0 \\
14\end{array}$ & $\begin{array}{r}2 \\
48\end{array}$ & $\begin{array}{l}74 \\
38\end{array}$ & $\begin{array}{r}24 \\
1\end{array}$ & $\begin{array}{l}0 \\
0\end{array}$ & $\begin{array}{l}54 \\
88\end{array}$ & $<1 \%$ \\
\hline M1 & $\begin{array}{l}104 \\
162\end{array}$ & $\begin{array}{r}2 \\
11\end{array}$ & $\begin{array}{r}6 \\
43\end{array}$ & $\begin{array}{l}38 \\
37\end{array}$ & $\begin{array}{r}51 \\
9\end{array}$ & $\begin{array}{l}3 \\
0\end{array}$ & $\begin{array}{r}321 \\
35\end{array}$ & $<1 \%$ \\
\hline M2 & $\begin{array}{l}103 \\
180\end{array}$ & $\begin{array}{l}0 \\
3\end{array}$ & $\begin{array}{r}6 \\
29\end{array}$ & $\begin{array}{l}56 \\
46\end{array}$ & $\begin{array}{l}38 \\
23\end{array}$ & $\begin{array}{l}0 \\
0\end{array}$ & $\begin{array}{l}32 \\
35\end{array}$ & $3 \%$ \\
\hline M3 & $\begin{array}{l}105 \\
185\end{array}$ & $\begin{array}{l}7 \\
5\end{array}$ & $\begin{array}{r}7 \\
24\end{array}$ & $\begin{array}{l}48 \\
56\end{array}$ & $\begin{array}{l}37 \\
15\end{array}$ & $\begin{array}{l}0 \\
0\end{array}$ & $\begin{array}{l}27 \\
41\end{array}$ & $8 \%$ \\
\hline M4 & $\begin{array}{l}114 \\
193\end{array}$ & $\begin{array}{l}0 \\
6\end{array}$ & $\begin{array}{l}18 \\
21\end{array}$ & $\begin{array}{l}60 \\
56\end{array}$ & $\begin{array}{l}22 \\
15\end{array}$ & $\begin{array}{l}0 \\
1\end{array}$ & $\begin{array}{l}45 \\
80\end{array}$ & $>15 \%$ \\
\hline P1 & $\begin{array}{l}106 \\
177\end{array}$ & $\begin{array}{r}3 \\
10\end{array}$ & $\begin{array}{l}56 \\
56\end{array}$ & $\begin{array}{l}41 \\
29\end{array}$ & $\begin{array}{l}0 \\
5\end{array}$ & $\begin{array}{l}0 \\
0\end{array}$ & $\begin{array}{r}400 \\
66\end{array}$ & $<1 \%$ \\
\hline $\mathrm{P} 2$ & $\begin{array}{l}113 \\
187\end{array}$ & $\begin{array}{r}2 \\
12\end{array}$ & $\begin{array}{l}42 \\
63\end{array}$ & $\begin{array}{l}54 \\
23\end{array}$ & $\begin{array}{l}2 \\
0\end{array}$ & $\begin{array}{l}0 \\
0\end{array}$ & $\begin{array}{r}670 \\
56\end{array}$ & $<1 \%$ \\
\hline $\mathrm{A} 1$ & $\begin{array}{l}106 \\
168\end{array}$ & $\begin{array}{l}28 \\
37\end{array}$ & $\begin{array}{l}68 \\
58\end{array}$ & $\begin{array}{l}4 \\
6\end{array}$ & $\begin{array}{l}0 \\
0\end{array}$ & $\begin{array}{l}0 \\
0\end{array}$ & $\begin{array}{l}69 \\
71\end{array}$ & $>15 \%$ \\
\hline $\mathrm{A} 2$ & $\begin{array}{l}112 \\
179\end{array}$ & $\begin{array}{l}13 \\
38\end{array}$ & $\begin{array}{l}74 \\
59\end{array}$ & $\begin{array}{r}13 \\
7\end{array}$ & $\begin{array}{l}0 \\
0\end{array}$ & $\begin{array}{l}0 \\
0\end{array}$ & $\begin{array}{r}128 \\
37\end{array}$ & $<1 \%$ \\
\hline $\mathrm{C} 1$ & $\begin{array}{c}124 \\
190-235\end{array}$ & $\begin{array}{l}0 \\
0\end{array}$ & $\begin{array}{l}10 \\
10\end{array}$ & $\begin{array}{l}76 \\
65\end{array}$ & $\begin{array}{l}14 \\
25\end{array}$ & $\begin{array}{l}0 \\
0\end{array}$ & $\begin{array}{r}380 \\
35\end{array}$ & $>15 \%$ \\
\hline $\mathrm{C} 2$ & $\begin{array}{l}115 \\
231\end{array}$ & $\begin{array}{l}0 \\
3\end{array}$ & $\begin{array}{l}15 \\
28\end{array}$ & $\begin{array}{l}77 \\
69\end{array}$ & $\begin{array}{l}8 \\
0\end{array}$ & $\begin{array}{l}1 \\
0\end{array}$ & $\begin{array}{r}168 \\
39\end{array}$ & $2 \%$ \\
\hline C3 & $\begin{array}{c}116 \\
221-233\end{array}$ & $\begin{array}{l}2 \\
4\end{array}$ & $\begin{array}{l}25 \\
25\end{array}$ & $\begin{array}{l}70 \\
65\end{array}$ & $\begin{array}{l}3 \\
4\end{array}$ & $\begin{array}{l}0 \\
0\end{array}$ & $\begin{array}{r}122 \\
24\end{array}$ & $>15 \%$ \\
\hline $\mathrm{C} 4$ & $\begin{array}{l}110 \\
187\end{array}$ & $\begin{array}{l}0 \\
4\end{array}$ & $\begin{array}{r}1 \\
15\end{array}$ & $\begin{array}{l}40 \\
59\end{array}$ & $\begin{array}{l}59 \\
22\end{array}$ & $\begin{array}{l}0 \\
0\end{array}$ & $\begin{array}{l}80 \\
54\end{array}$ & $<1 \%$ \\
\hline C5 & $\begin{array}{l}150 \\
208\end{array}$ & $\begin{array}{l}1 \\
0\end{array}$ & $\begin{array}{r}3 \\
23\end{array}$ & $\begin{array}{l}38 \\
55\end{array}$ & $\begin{array}{l}57 \\
21\end{array}$ & $\begin{array}{l}2 \\
0\end{array}$ & $\begin{array}{r}336 \\
47\end{array}$ & $<1 \%$ \\
\hline
\end{tabular}

(1) $P\left(\chi^{2}\right)$ gives the probability that the 2 distributions are drawn from the same population. 
fects of this factor on seedling growth could only be demonstrated by comparing the size of sameday emergers.

\section{Space variations in seedling size distributions}

\section{Influence of surface structure}

Table III shows that SG distributions were significantly influenced by seedbed structure. Low SG were slightly more frequent when the seedbed was prepared with simplified operations which created a coarse surface structure. A similar trend was observed when there was severe surface crusting due to a heavy rainfall just after sowing. Seedling size distributions were compared for areas covered by the same type of crust, regardless of their plot location (table IV). Significant differences were found between the 3 typical situations, corresponding to more or less crusted seedbeds. The SG distribution tended to be lower when soil crusts were more developed.

\section{Row effects}

Comparison of the size distributions for different rows were made for an emergence date of 20/4/ 1988 , because this date allowed SG distributions for large numbers of plants (113 to $153 \mathrm{ac}$ cording to the row) to be compared.

The results are shown in figure 2. The SG distributions were again significantly different $\left(P\left(\chi^{2}\right)<1 \%\right)$. Rows Nos 1, 18, 19, 23 had more plants of small size, while rows Nos 6, 7, 12, 14, 22 had larger plants.

Table III. Seedling size for different seedbed structures.

\begin{tabular}{|c|c|c|c|c|c|c|c|c|c|}
\hline \multirow{2}{*}{$\begin{array}{c}\text { Emergence } \\
\text { date } \\
\text { STT } \\
\left({ }^{\circ} \mathrm{C} \text { days }\right)\end{array}$} & \multirow[t]{2}{*}{$\begin{array}{l}\text { Experimental } \\
\text { treatment }\end{array}$} & \multirow[t]{2}{*}{$\begin{array}{l}\text { Seedbed } \\
\text { structure }\end{array}$} & \multirow{2}{*}{$\begin{array}{l}\text { Sample } \\
\text { size } \\
\text { (n) }\end{array}$} & \multicolumn{5}{|c|}{$\begin{array}{c}\text { Size grade } \\
\text { (\% seedlings) }\end{array}$} & \multirow[t]{2}{*}{$P\left(\chi^{2}\right)$} \\
\hline & & & & 1 & 2 & 3 & 4 & 5 & \\
\hline \multicolumn{10}{|l|}{$22 / 04 / 1987$} \\
\hline 153 & M1 & Fine & 101 & 1 & 6 & 74 & 19 & 0 & $<1 \%$ \\
\hline 157 & M3 & Coarse & 94 & 3 & 19 & 54 & 23 & 0 & \\
\hline \multicolumn{10}{|l|}{$23 / 04 / 1988$} \\
\hline 181 & $\mathrm{C} 1$ & Fine & 32 & 0 & 6 & 72 & 22 & 0 & $<1 \%$ \\
\hline 169 & C3 & $\begin{array}{l}\text { Crusted } \\
(14 \mathrm{~mm})\end{array}$ & 55 & 2 & 16 & 70 & 11 & 0 & \\
\hline
\end{tabular}

Table IV. Influence of soil crusting on seedling size.

\begin{tabular}{|c|c|c|c|c|c|c|c|}
\hline \multirow[t]{2}{*}{ Crust type } & \multirow{2}{*}{$\begin{array}{l}\text { Emergence } \\
\text { date } \\
\text { STi } \\
\left({ }^{\circ} \mathrm{C} \text { days }\right)\end{array}$} & \multirow{2}{*}{$\begin{array}{l}\text { Sample } \\
\text { size } \\
\text { (n) }\end{array}$} & \multicolumn{5}{|c|}{ Size grade (\% seedlings) } \\
\hline & & & 1 & 2 & 3 & 4 & 5 \\
\hline No crust & $\begin{array}{l}21 / 4 \\
155\end{array}$ & 97 & 1 & 5 & 46 & 46 & 1 \\
\hline Structural & $\begin{array}{l}22 / 4 \\
157\end{array}$ & 180 & 1 & 14 & 74 & 11 & 0 \\
\hline Depositional & $\begin{array}{l}22 / 4 \\
157\end{array}$ & 126 & 2 & 24 & 70 & 3 & 0 \\
\hline
\end{tabular}

$P\left(\chi^{2}\right)<1 \%$. 


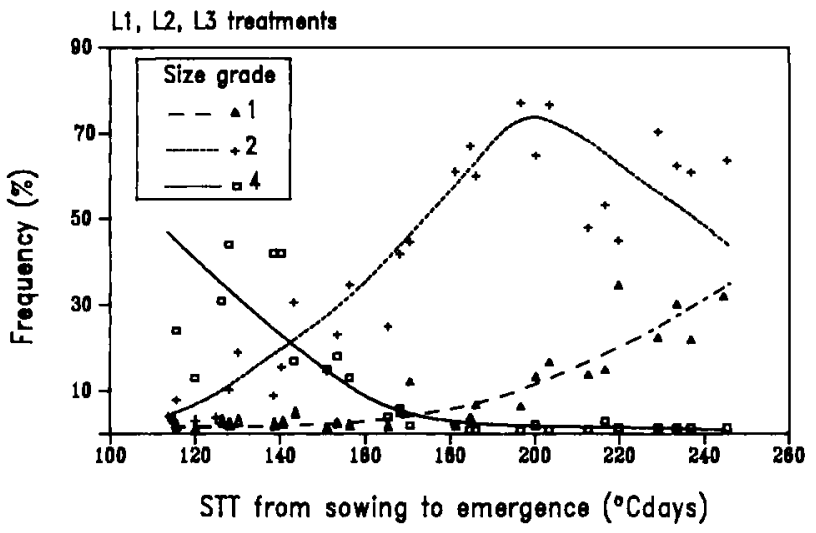

Fig 1. Influence of emergence delay on seedling size distributions. Lines are hand-fitted curves.

\section{Relations between seedling size, plant morphology and seedbed structure close to the seedling}

The plants whose individual environments were monitored could be classified into 2 groups according to the presence or absence of an obstacle in the path of their hypocotyl. The obstacles were clods, small stones, straw fragments or compact microlayers. Seventy-three percent of seedlings that encountered such obstacles had deformed hypocotyls. Obstacles were significantly associated with small plants (table V). This was true for comparisons of the SG distributions for several emergence dates grouped together, and when only plants having emerged on the same day were considered, although there were few plants in these cases.

Table $\mathrm{V}$. Influence of obstacles on the frequency of large seedlings (A) for different emergence days together, (B) for a single emergence day (20/04/1988).

\begin{tabular}{|c|c|c|c|c|}
\hline \multirow{2}{*}{\multicolumn{2}{|c|}{ Comparison }} & \multicolumn{2}{|c|}{$\begin{array}{c}\text { Obstacles } \\
\text { on hypocotyl course }\end{array}$} & \multirow[t]{2}{*}{$P\left(\chi^{2}\right)$} \\
\hline & & Yes & No & \\
\hline \multirow[t]{2}{*}{ A } & $\%$ SG $(4+5)$ & 34 & 64 & $<1 \%$ \\
\hline & $n$ & 131 & 60 & \\
\hline \multirow[t]{2}{*}{ B } & $\%$ SG $(4+5)$ & 8 & 37 & $<1 \%$ \\
\hline & $n$ & 49 & 19 & \\
\hline
\end{tabular}

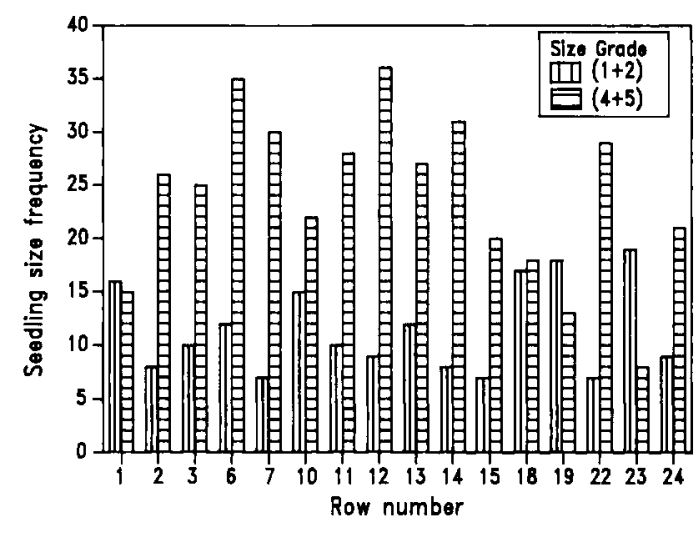

Fig 2. Seedling size distribution in the different rows.

\section{DISCUSSION}

\section{Seedling size and emergence delay}

The relationship between emergence delay and seedling size distribution suggests that at least one part of the variability of seedling growth is generated before emergence. This is supported by examination of cotyledon elongation before SG assessment (fig 3): SG were discriminated at the very beginning of autotrophic growth, because even $60^{\circ} \mathrm{C}$ days after emergence the corresponding cotyledon lengths were different.

Different ways of interpretation can account for a negative correlation between seedling size and emergence delay, as shown by figure 4 . A first group of hypotheses $(\mathrm{H} 1)$ is based on the influence of seed characteristics, which are very variable in the case of sugar beet, even within a single seed lot. For instance, the dry weights of the true seeds in this lot varied over a 2-fold range. The influence of intrinsic seed characteristics may be either direct $(\mathrm{H} 1 \mathrm{a})$ or indirect $(\mathrm{H} 1 \mathrm{~b})$. The direct hypothesis assumes that early emergence is related to a rapid growth of seedlings before emergence, and that this individual potential continues to be expressed after emergence. According to the indirect hypothesis, seed characteristics only influence seedling size through emergence delay: increased emergence delay causes a decrease in seedling size.

The second interpretation $(\mathrm{H} 2)$ is based on environmental effects. Seedbed conditions affecting emergence delay could affect seedling size through direct effects $(\mathrm{H} 2 \mathrm{a})$ or indirect effects induced by emergence delay ( $\mathrm{H} 2 \mathrm{~b})$. 
The above hypotheses are not mutually exclusive, but are associated with distinct spatial patterns of seedling size distribution. For instance, the correlations between seedling size and sowing depth predicted by each hypothesis differ. According to $\mathrm{H} 1 \mathrm{~b}$ or $\mathrm{H} 2 \mathrm{~b}$, seedlings having the same emergence delay but coming from seeds placed at different depths should not exhibit systematic differences in size. Conversely, according to $\mathrm{H} 1 \mathrm{a}$ and or $\mathrm{H} 2 \mathrm{a}$, and considering the absence of dry conditions ciuring germination, seedlings derived from deeply sown seeds should exhibit greater size than same-day emergers derived from shallower seeds, since they had faster growth rates before emergence. These hypotheses were tested by comparing seedling size distribution for 3 pairs of plots with contrasted sowing depths. In 2 cases (one shown in fig 5), a deeper sowing was associated with greater seedling size for a given emergence delay, in accordance with $\mathrm{H} 1 \mathrm{a}$ and $\mathrm{H} 2 \mathrm{a}$. Consequently, the negative relationship between emergence delay and seedling size is at least partly due to the fact that the earlier emerging seedlings also have faster subsequent growth rates.

Nevertheless, emergence delay may have a causal influence on seedling growth, because there is no evidence that the direct effects of seed characteristics and/or seedbed conditions fully explain the relationship between seedling size and emergence delay. Delayed emergence

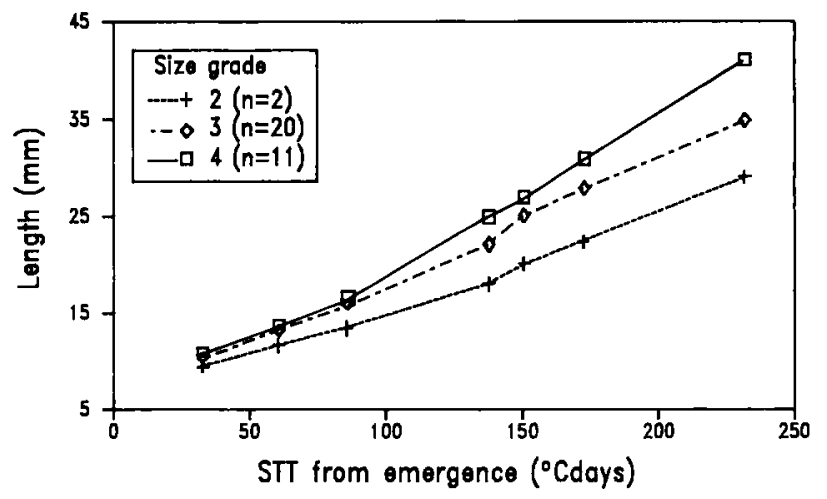

Fig 3. Cotyledon elongation for different seedling size grades.

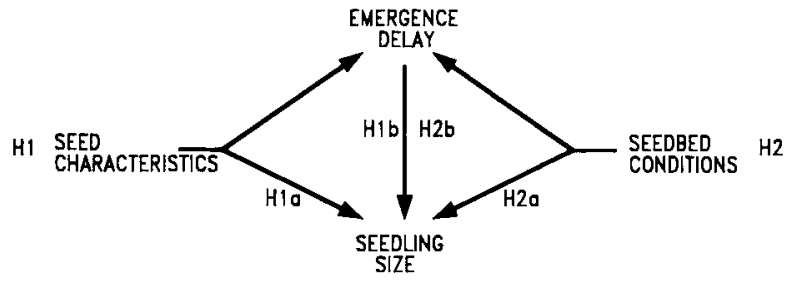

Fig 4. Hypotheses for the origins of differences in seedling size. could result in greater consumption of seed reserves for respiration and/or hypocotyl growth. This could reduce the size and weight of cotyledons and decrease the rate of autotrophic growth after emergence. Measurements of seedling weight made 5 days after emergence $\left(60^{\circ} \mathrm{C}\right.$ days) show total dry weights about 2 times greater than true seed weights (fig 6) which range from 1.5 to $4.5 \mathrm{mg}$. Full autotrophic growth is probably achieved soon after emergence. In the case of species with epigeal emergence, early growth depends on the state and efficiency of cotyledons. Black (1956) observed that clover seedlings at emergence had cotyledon weights negatively correlated with sowing depths, without any influence on subsequent growth. But recent data obtained on carrots (Durr et al, 1990) and sugar beet indicate that long emergence delays can induce degradation of cotyledon material, this resulting in a decrease of seedling growth rate.

\section{Environmental effects on seedling size}

Seed characteristics are expected to be randomly distributed in space during the sowing operation when using the same seed lot and coated

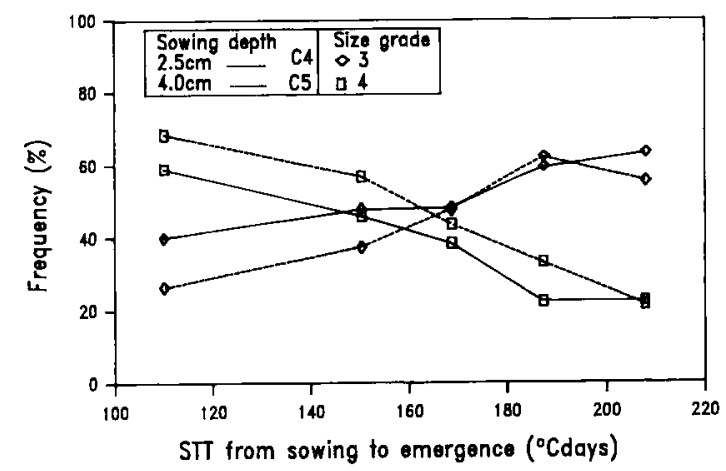

Fig 5. Seedling size distributions for different depths of sowing.

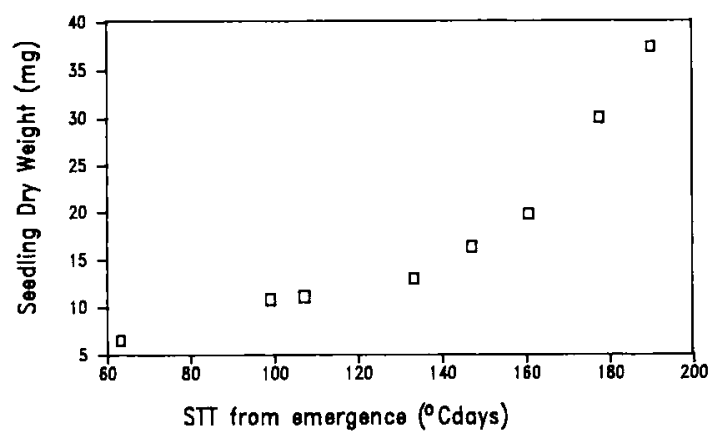

Fig 6. Changes in seedling weight after emergence. 
seeds. Hence, the observed systematic deviations of seedling size distribution between rows or between plots support the hypothesis $\mathrm{H} 2$. The likelihood of $\mathrm{H} 2 \mathrm{a}$ is also supported by the fact that such deviations occur even when emergence delays are identical.

The observed row effects are not attributable to a direct influence of drilling operations, because pairs of rows sown by the same drill unit, but on different drill passes (eg 1-24, 2-23, 718 ), had different seedling size distributions. Hence, row effects can be attributed to seedbed conditions induced by previous tillage operations. Surface structure observations suggested that the rows with most small plants were more cloddy than those having most large plants, but these observations were not accurate enough to be statistically validated.

The influence of surface structure on seedling size distribution is clearly demonstrated when observations are made on an appropriate scale. This is the case when surface structure is characterized for row segments having similar crusting features, or better still, for the environment of the individual plant. It is then evident that mechanical obstacles encountered before emergence, such as topsoil crusts, clods or other discontinuities, can direcly affect subsequent seedling growth.

The results reported here do not allow a more detailed investigation of the biological processes involved in this phenomenon. The morphological and growth responses to mechanical stress have been reported by several authors (Garner and Bowen, 1966; Barley and Greacen, 1967; Wanjura and Buxton, 1972; Knittle and Buris, 1979; Braunack and Dexter, 1989). This type of response is in some cases associated with the internal production of ethylene or hormones (Goeschl et al, 1966; Hegarty and Royle, 1976; Biddington and Dearman, 1987; Latimer and Mitchell, 1988). Such physiological processes could also induce alterations in the allocation of seed reserves to the different seedling organs (Ishizawa and Esashi, 1988). Seedlings having a same total biomass at emergence, but different distributions of this biomass between cotyledons, primary root and hypocotyl, could exhibit differences in autotrophic growth rate.

Figure 7 summarizes the factors that may give rise to the variability in seedling size. Once the true leaves are functioning, the RGR is fairly constant, whatever the seedling size (Boiffin et al, 1992).

\section{CONCLUSION}

The variability of sugar beet seedling size, evaluated at 4 visible leaves, is at least partly inherited from processes occurring prior to emergence. Delayed emergence appears to be associated with smaller seedling size. This tendency may be due to: i) the variability of seed characteristics; ii) environmental effects related to seedbed heterogeneity; iii) a direct causal influence of emergence delay on seedling growth.

Seedling size assessed for a given emergence delay is not randomly distributed in space, implying that environmental factors may influence the very early stages of growth. In our experimental conditions, the environmental effects on seedling growth were related to seedbed structure. Mechanical obstacles, such as crusts and clods are associated with smaller size of seedlings, even when emergence delays are the same. These effects could be the physiological consequences of mechanical stress.

As sugar beet growth is exponential until approximately late June in north western Europe, seedling size heterogeneity is probably a significant source of between and within-field variability in light interception efficiency. Our data suggest that this heterogeneity can be partly controlled by seedbed preparation, seed placement and the choice of sowing date in relation to probable rainfall. Optimal conditions appear to be the same for increasing emergence rate, reducing its duration and increasing seedling growth.

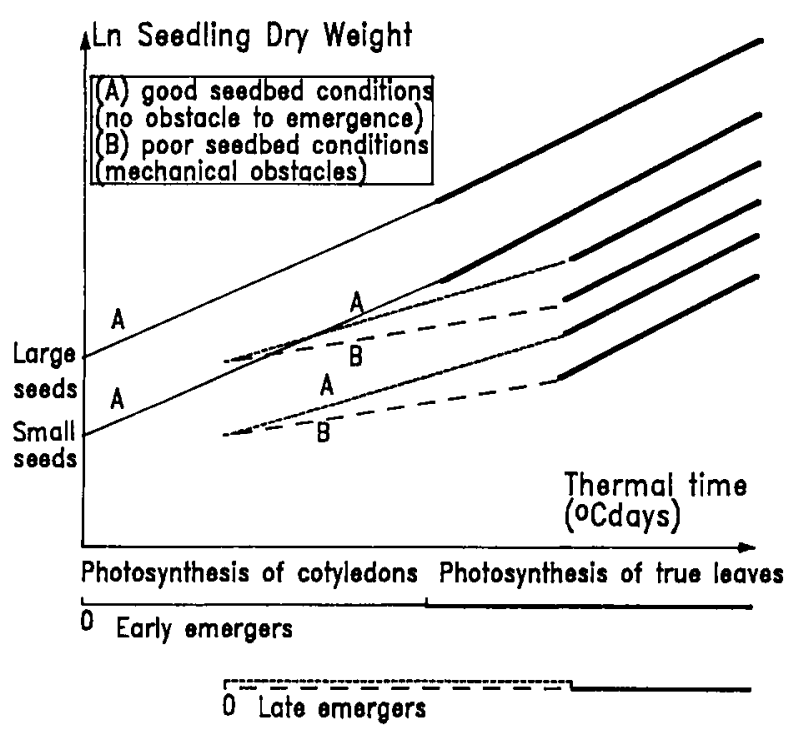

Fig 7. Possible seedling growth patterns after emergence. 


\section{REFERENCES}

Barley KP, Greacen EL (1967) Mechanical resistance as a soil factor influencing the growth of roots and underground shoots. Adv Agron 19, 1-43

Biddington NL, Dearman AS (1987) The effects of mechanically-induced stress and plant growth regulators on the growth of lettuce, cauliflower and bean (Phaseolus vulgaris L) plants. Plant Growth Regul 5, 183-194

Black JN (1956) The influence of seed size and depth of sowing on pre-emergence and early vegetative growth of subterraneum clover (Trifolium subterraneum L). Aust J Agric Res 7, 98-109

Boiffin J (1984) La dégradation structurale des couches superficielles du sol sous l'action des pluies. Thèse DI, INA Paris-Grignon

Boiffin J (1986) Stages and time depency of soil crusting in situ. In: Assessment of Soil Surface Sealing and Crusting (Callebaut F, Gabriels, de Boodt M, eds) Flanders Res Center Soil Erosion Soil Conserv, Ghent, 91-98

Boiffin J, Bresson LM (1987) Dynamique de formation des croûtes superficielles : apport de l'analyse microscopique. In : Micromorphologie des Sols - Soil Micromorphology (Feodoroff N, Bresson LM, Courty MO, eds) AFES Plaisir, 393-399

Boiffin J, Durr C, Fleury A, Marin-Laflèche A (1992) Analysis of the variability of sugar beet (Beta vulgaris $\mathrm{L}$ ) growth during the early stages. I. Influence of various conditions of crop establishment. Agronomie 12,

Braunack MV, Dexter AR (1989) Soil aggregation in the seedbed: a review. II. Effect of aggregate sizes on plant growth. Soil Tillage Res 14, 281-298

Bresson LM, Boiffin J (1990) Morphological characterisation of soil crust development stages on an experimental field. Geoderma 47, 307-325

Donald RG, Kay BD, Miller H (1987) The effect of soil aggregate size on early shoot and root growth of maize (Zea mays L). Plant Soil 103, 251-259

Durr C, Tamet V, Boiffin J (1990) Redistribution of seed reserves during the emergence of carrot seedlings and its influence on subsequent growth. Proc 1st Congr European Soc Agron, S1P43

Durrant MJ, Mash SJ (1989) Stimulation of sugar beet hypocotyl extension with potassium nitrate. Ann Appl Biol 115, 367-374
Fleury A, Caneill J (1984) Croissance et développement de la betterave sucrière. Analyse de l'hétérogénéité du peuplement. In : Physiologie de la Plante Entière. INRA Agronomie, Paris, 201-212

Garner TH, Bowen HD (1966) Plant mechanics in seedling emergence. Am Soc Agric Eng Trans 9, 650-653

Goeschl JD, Rappaport L, Pratt HK (1966) Ethylene as a factor regulating the growth of pea epycotyls subjected to physical stress. Plant Physiol 41, 877 884

Hammerton JL (1961) Studies of the effects of soil aggregate size on the emergence and growth of beet (Beta vulgaris L). II. Leaf development. J Agric Sci Camb 56, 417-429

Hegarty TW, Royle SM (1976) Impedance of calabrese seedling emergence from light soils after rainfall. Hortic Res 16, 107-114

Ishizawa K, Esashi $Y$ (1988) Action mechanism of ethylene in the control of sugar translocations in relation to rice coleoptile growth. I. Sucrose metabolism. Plant Cell Physiol 29, 131-141

Knittle KH, Burris JS (1979) Effect of downward force on soybean hypocotyl growth. Crop Sci 19, 47-51

Latimer JG, Mitchell C (1988) Effect of mechanical stress or abscissic acid on growth, water status and leaf abscissic acid content of eggplant seedlings. Scientia Hortic 36, 37-46

Milford GF, Biscoe PV, Jaggard KW, Scott RK, Draycott AP (1980) Physiological potential for increasing yields of sugar beet. In: Opportunities for Increasing Crop Fields (Hurd RG, Biscoe PV, Dennis $C$, eds) London, 710-783

Scott JM, Blair G (1988) Phosphorus seed coatings for pasture species. 1. Effect of source and rate of phosporus on emergence and early growth of phalaris (Phalaris aquatica $\mathrm{L}$ ) and lucerne (Medicago sativa L). Aust J Agric Res 39, 447-455

Scott RK, Harper F, Wood DW, Jaggard KW (1974) Effects of seed size on growth, development, and yield of monogerm sugar beet. J Agric Sci (Camb) $82,517-530$

Scott RK, Jaggard KW (1978) Theoretical criteria for maximum yield. Proc 41st Winter Congr IISBR. Brussels, 179-198

Wanjura DF, Buxton DR (1972) Hypocotyl and radicle elongation of cotton as affected by soil environment. Agron J 64, 431-434 